\title{
Halorubrum tebenquichense sp. nov., a novel halophilic archaeon isolated from the Atacama Saltern, Chile
}

\author{
1 Department of Chemistry \\ and Biology, Faculty of \\ Natural Sciences, University \\ of Atacama, Avd. \\ Copayapu 485, Copiapó, \\ Chile \\ 2 Department of \\ Microbiology, Faculty of \\ Pharmacy, University of \\ Granada, C/Cartuja S/N \\ 18071 Granada, Spain \\ 3 Department of \\ Biochemistry, Faculty of \\ Pharmacy, University of \\ Granada, C/Cartuja S/N \\ 18071 Granada, Spain \\ 4 Max-Planck-Institut für \\ Marine Mikrobiologuie, \\ Celsius-straße 1, D-28359 \\ Bremen, Germany \\ 5 Laboratory of \\ Microbiology, Institute of \\ Biology, Faculty of Basic \\ and Mathematics Sciences, \\ Catholic University of \\ Valparaíso, Avenida Brasil \\ 2950 Valparaíso, Chile
}

\author{
Catherine Lizama, ${ }^{1,2}$ Mercedes Monteoliva-Sánchez, ${ }^{2}$ \\ Antonio Suárez-García, ${ }^{3}$ Ramón Roselló-Mora, ${ }^{4}$ Margarita Aguilera, ${ }^{2}$ \\ Victoriano Campos ${ }^{5}$ and Alberto Ramos-Cormenzana ${ }^{2}$
}

Author for correspondence: Mercedes Monteoliva-Sanchez. Tel: +34 958 243875. Fax: +34 958246235. e-mail:mmonteol@platon.ugr.es

\begin{abstract}
A novel extremely halophilic archaeon was isolated from Lake Tebenquiche, situated in the northern part of the Atacama Saltern, Chile. The cells of these micro-organisms were mostly irregularly disc-shaped. They grew in medium containing saturated concentrations of $\mathrm{NaCl}$ and did not require magnesium for optimal growth. The polar lipid composition revealed the presence of mannosyl-2-sulfate-(1-4)-glycosyl-archaeol, the main glycolipid of the genus Halorubrum, and two new glycolipids. The G+C content of the DNA was $63.2 \mathrm{~mol} \%$. Phylogenetic analysis of the 16S rRNA gene placed strain ALT6-92 ${ }^{\top}$ within the Halorubrum cluster. The low DNA-DNA hybridization value justified classification in a new species for which the name Halorubrum tebenquichense

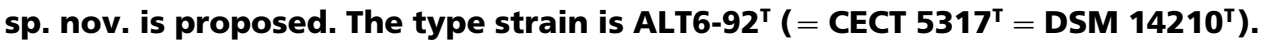

Keywords: extremely halophilic archaea, Halorubrum tebenquichense, Lake Tebenquiche, Atacama Saltern

\section{INTRODUCTION}

The extremely halophilic archaea are the dominant microbial populations of hypersaline environments. Hypersaline ecosystems such as salt lakes and marshes show great variability in total salt concentration, ionic composition and $\mathrm{pH}$ (Ollivier et al., 1994). The current classification of halophilic archaea is based on three kinds of data: phenetic data, chemical data and genetic data (16S rRNA sequence information and DNADNA hybridization results) (Oren et al., 1997).

The Atacama Saltern is located in Northern Chile and covers an area of $32000 \mathrm{~km}^{2}$. Because of its location in the Atacama Desert at $2300 \mathrm{~m}$ above sea level, it is a unique environment. Previous studies have shown that the microbiota of Lake Tebenquiche, situated in the northern part of the saltern, consist of a heterogeneous group of extremophile micro-organisms (Campos et al., 1990; Prado et al., 1991, 1993).

Abbreviations: S-DGD-3, mannosyl-2-sulfate-(1-4)-glycosyl-archaeol; SDGD-5, mannosyl-2-sulfate-(1-2)-glycosyl-archaeol.

The GenBank/EMBL/DDBJ accession number for nucleotide sequence of strain ALT6-92 ${ }^{\top}$ is AJ276887.
Eighty two strains of extremely halophilic archaea were collected between 1984 and 1995, in the Lake Tebenquiche and Poligonal Zone of the Atacama Saltern. Polar lipid analyses (particularly of glycolipids) suggested that 12 of them were associated with the genus Halorubrum. Two strains (designated ALT6-92 ${ }^{\mathrm{T}}$ and TeSe25-84) possessed similar phenotypes as well as unique features that did not correspond to any previosly described species (Grant \& Larsen, 1990; Kamekura \& Dyall-Smith, 1995; Kamekura et al., 1997). Strain ALT6-92 ${ }^{\mathrm{T}}$ was chosen for further characterization. On the basis of $16 \mathrm{~S}$ rRNA sequences, glycolipid content and phenotypic characterization, we propose to classify this strain as a member of a new species, namely Halorubrum tebenquichense sp. nov.

\section{METHODS}

Strains and culture conditions. The strains were collected from Lake Tebenquiche between 1984 and 1992. The reference strains of Halorubrum used in this study are listed in Table 1.

HE medium (Torreblanca et al., 1986) was prepared with $25 \%(\mathrm{w} / \mathrm{v})$ total salts, according to Subov (1931), and supplemented with $0 \cdot 1 \%$ glucose. The $\mathrm{pH}$ was adjusted to 
Table 1. DNA base composition, DNA-DNA relatedness and evolutionary distance results for Halorubrum strains isolated from the Atacama Saltern and species of the genus Halorubrum

\begin{tabular}{|lcccc|}
\hline Strain & $\begin{array}{c}\text { G+C content } \\
\text { (mol \%) }\end{array}$ & \multicolumn{2}{c|}{\begin{tabular}{c} 
Similarity (\%) to: \\
\cline { 3 - 4 }
\end{tabular}} & $\begin{array}{c}\text { Evolutionary distance } \\
\text { with ALT6-92 }^{\mathbf{T}}\end{array}$ \\
\hline ALT6-92 & TeSe25-84 & \\
TeSe25-84 & $63 \cdot 2$ & 100 & $90 \cdot 57$ & 0 \\
H. sodomense DSM 3757 & $62 \cdot 5$ & $95 \cdot 65$ & 100 & $0 \cdot 0156$ \\
H. saccharovorum DSM 1137 & $68^{*}$ & $55 \cdot 5$ & $35 \cdot 79$ & $0 \cdot 0346$ \\
H. trapanicum CECT 397 & $71 \cdot 2^{*}$ & $40 \cdot 84$ & $23 \cdot 49$ & $0 \cdot 0564$ \\
H. distributum VKM B-1733 & $64 \cdot 3^{*}$ & 42 & $25 \cdot 63$ & $0 \cdot 0331$ \\
H. lacusprofundi DSM 5036 & ND & 45 & $30 \cdot 54$ & $0 \cdot 0483$ \\
H. coriense DSM 10284 & ND $3-65 \cdot 8^{*}, 54 \cdot 8-56 \cdot 5$ (minor component) & $44 \cdot 06$ & $22 \cdot 84$ & $0 \cdot 0682$ \\
H. vacuolatum DSM 8800 & $62 \cdot 7^{*}$ & $43 \cdot 14$ & $23 \cdot 24$ & $0 \cdot 0394$ \\
\hline
\end{tabular}

ND, Not determined.

* Data obtained from Oren (1983), Grant \& Larsen (1990), Mwatha \& Grant (1993) and McGenity \& Grant (1995).

$7 \cdot 0$ with $4 \mathrm{M} \mathrm{NaOH}$. Liquid medium was solidified by adding $2 \%$ agar before sterilization.

The characterization of isolates, including morphological, physiological, biochemical, nutritional and antimicrobialsusceptibility testing, was performed for each strain, as described previously (Tomlinson \& Hochstein 1976; Tomlinson et al., 1986; Rodríguez-Valera \& RuizBerraquero, 1983; Rodríguez-Valera et al., 1980, 1982; Tindall et al., 1984; González et al., 1978; Juez et al., 1986; Torreblanca et al., 1986). Gram staining was performed by using acetic acid-fixed samples as described by Dussault (1955). Cell shape was examined by optical microscopy (standard 25; Zeiss). Transmission electron microscopy was carried out with cells grown in HE broth at $25 \%(\mathrm{w} / \mathrm{v})$ overlying HE agar plates at $25 \%(\mathrm{w} / \mathrm{v})$ total salts. Samples were negatively stained with $2 \%(\mathrm{w} / \mathrm{v})$ uranyl acetate $(30 \mathrm{~s})$ and washed with an acetic acid solution at $3 \%(\mathrm{w} / \mathrm{v})$. Observation was made using a high-resolution transmission electron microscope at $80 \mathrm{~kW}$ (TEM 902; Zeiss).

Lipid analysis. Lipids were extracted by the method of Bligh $\&$ Dyer (1959) as described by Kates (1972). The lipids were separated using silica gel TLC (Kiesel gel $60 \mathrm{~F}_{254}$; Merck) and simple development with a chloroform/methanol/acetic acid/water $(85: 22: 5: 10: 4$ by vol.) solvent system. In addition, two-dimensional chromatography was performed by using chloroform/methanol/water $(65: 25: 4$ by vol.) in the first dimension and chloroform/methanol/acetic acid/water (80:12:15:4 by vol.) in the second dimension (Tindall et al., 1987; Oren et al., 1996). Phospholipids were visualized with an ammonium molybdate/sulfuric acid spray. Glycolipid spots were detected by spraying the plates with $0.5 \% \alpha$ naphthol in $50 \%$ methanol and then with $5 \% \mathrm{H}_{2} \mathrm{SO}_{4}$ in ethanol and heating them at $150^{\circ} \mathrm{C}$ (Kates, 1972).

DNA isolation, $\mathrm{G}+\mathrm{C}$-content determination and DNA-DNA hybridization. The DNA was isolated and purified by the method described by Lind \& Ursing (1986). The G+C content $(\mathrm{mol} \%)$ was determined by the thermal denaturation method $\left(T_{\mathrm{m}}\right)$ (Marmur \& Doty, 1962) with a Perkin-Elmer Lambda 3B spectrophotometer fitted with a temperature program accessory. DNA-DNA hybridization studies were performed with the non-radioactive method described by Ziemke et al. (1998). Reference DNA was double-labelled using DIG-11-dUTP and biotin-16-dUTP (Boehringer Mannheim). The labelling reaction was carried out using the Boehringer Mannheim nick-translation kit.

PCR amplification of the 16S rRNA gene coding sequence, and sequencing. Purified genomic DNA was used for PCR amplification of the 16S rDNA gene. The following two primers were designed to complement the highly conserved regions of the Halobacterium salinarum and Halorubrum spp. 16S rDNA: forward primer F8 (5'-TTGATCCTGCCGGAGGCCATTG-3') and reverse primer R1462 (5'ATCCAGCCGCAGATTCCCCTAC-3), corresponding to positions 8-30 and 1462-1441, respectively. The oligonucleotides were produced by Pharmacia Biotech and then were diluted to $100 \mathrm{pmol}^{-1} \mathrm{l}^{-1}$. The PCR was performed in a thermal cycler (model 480; Perkin-Elmer) for 30 cycles, starting with $1 \mathrm{~min}$ of denaturation at $94{ }^{\circ} \mathrm{C}$, followed by $1 \mathrm{~min}$ of annealing at $55^{\circ} \mathrm{C}$ and $2 \mathrm{~min}$ of elongation at $72{ }^{\circ} \mathrm{C}$. The mixture reaction (in a total volume of $100 \mu \mathrm{l}$ ) contained: $2 \mu$ l genomic DNA, $10 \mu \mathrm{l}$ buffer (100 mM Tris/ $\mathrm{HCl}, \mathrm{pH} 8 \cdot 3 ; 500 \mathrm{mM} \mathrm{KCl}), 4 \mu \mathrm{l} \mathrm{MgCl}_{2}(25 \mathrm{mM}), 1 \mu \mathrm{l}$ dNTP mixture (dATP, dCTP, dGTP, dTTP at $10 \mathrm{mM}$; Ultrapure dNTP set from Pharmacia Biotech) and $1 \mu \mathrm{Taq}$ DNA polymerase (Amplitaq DNA polymerase; PerkinElmer). Each primer was used at a concentration of 20 pmol $\mu \mathrm{l}^{-1}$. The PCR products were analysed by electrophoresis in $1.7 \%$ agarose gels in TAE buffer, using $\lambda$ PST1 as the size marker. The products were purified with Microcon100 concentrators (Amicon).

The following four sequencing primers were used to determine the complete 16S rRNA sequence: r1 (5'-TACCGTGAGGCGTCCTGTTAA-3'); r2 (5'-TTGTCTCGACCATTGTAGCC-3'); r3 (CCCGCCAATTCCTTTAAGTTTC- $3^{\prime}$ ) and $\mathrm{r} 4$ (5'-TGGCACCGGTCTTGCCCAG-3'). These primers were designed to complement regions 1011$1032,1197-1178,870-849$ and $458-440$, respectively. The purified PCR products were sequenced directly using a Strech Applied Biosystems ABI 373 DNA sequencer and the manufacturer's protocols for AmpliTaq ${ }^{\mathrm{r}} \mathrm{FS}$ with fluorescent dye-labelled dideoxynucleotides (ABI PRISM BigDye Terminator Cycle Sequencing Ready Reaction Kit; PerkinElmer) as described by Sanger et al. (1977). The sequences 
Table 2. Phenotypic characteristics and lipid composition of the strains ALT6-92 ${ }^{\top}$ and TeSe25-84 (isolated from the Atacama Saltern) in comparison with other Halorubrum species

Symbols: + , positive result; - , negative result; - ?, not detected; $+/-$, slight mark. All strains/species gave the same results in tests for the hydrolysis of Tween $40(-)$ and Tween $80(-)$, for the production of acid from arabinose $(-)$ and for the utilization of glucose $(-)$.

\begin{tabular}{|c|c|c|c|c|c|}
\hline Characteristic & ALT6-92 ${ }^{\mathrm{T}}$ & TeSe25-84 & H. sacharovorum & H. sodomense & H. trapanicum \\
\hline \multicolumn{6}{|l|}{$\begin{array}{l}\text { Growth in total salt } \\
\text { concentrations }(\%, \mathrm{w} / \mathrm{v}) \text { of: }\end{array}$} \\
\hline 10 & - & + & - & - & - \\
\hline 15 & + & + & - & + & - \\
\hline Growth at $50^{\circ} \mathrm{C}$ & + & + & $+^{*}$ & $+^{*}$ & - \\
\hline Growth at $\mathrm{pH} 6$ & - & - & + & - & - \\
\hline Catalase & + & + & $+^{*}$ & $+^{*}$ & $+^{*}$ \\
\hline Oxidase & + & + & $+^{*}$ & $+^{*}$ & $t^{*}$ \\
\hline \multicolumn{6}{|l|}{ Hydrolysis of: } \\
\hline Tween 20 & - & - & - & + & - \\
\hline Tween 60 & - & - & - & + & - \\
\hline Starch & - & - & $-*$ & $+^{*}$ & $-*$ \\
\hline Gelatin & - & - & $-*$ & $-*$ & $-*$ \\
\hline Aesculin & + & - & - & + & - \\
\hline Nitrate reduction & + & + & $-?^{*}$ & $+^{*}$ & $+^{*}$ \\
\hline Indole & - & - & $-*$ & $-*$ & $-{ }^{*}$ \\
\hline \multicolumn{6}{|l|}{ Acid from: } \\
\hline Xylose & - & - & + & + & - \\
\hline Fructose & - & + & + & + & + \\
\hline Glucose & - & - & + & + & + \\
\hline \multicolumn{6}{|l|}{ Utilization of: } \\
\hline Fructose & + & + & - & - & - \\
\hline Galactose & + & + & - & - & - \\
\hline Mannose & + & + & + & - & - \\
\hline Trehalose & + & + & - & - & - \\
\hline Starch & + & - & + & + & - \\
\hline Pyruvate & + & + & - & - & - \\
\hline Acetate & + & + & - & + & - \\
\hline \multicolumn{6}{|l|}{ Polar lipids } \\
\hline Phosphatidylglycerol (diether analogue) & + & + & $+^{*}$ & $+^{*}$ & $t^{*}$ \\
\hline Phosphatidylglycerolsulfate (diether analogue) & $-?$ & $+1-$ & $+*$ & $+*$ & $+*$ \\
\hline Phosphatidylglycerolphosphate (diether analogue) & + & + & $+^{*}$ & $+^{*}$ & $+^{*}$ \\
\hline Mannosyl-2-sulfate-(1-4)-glycosyl-archaeol & + & + & $+^{*}$ & $+^{*}$ & $-*$ \\
\hline Mannosyl-2-sulfate-(1-2)-glycosyl-archaeol & - & - & $-*$ & $-*$ & $+^{*}$ \\
\hline $\mathrm{X}_{1}$ (unknown glycolipid) & + & + & - & - & - \\
\hline $\mathrm{X}_{2}$ (unknown glycolipid) & + & + & - & - & - \\
\hline
\end{tabular}

* Data were obtained from Tomlinson \& Hochstein (1976), Oren (1983), Grant \& Larsen (1990) and McGenity \& Grant (1995).

were analysed using the ABI PRISM 373 xl Collection 2.0 and Sequencing Analysis 3.3 programs for Macintosh G3.

Phylogenetic analysis on the basis of 16S rRNA sequence. The sequence obtained was compared with previously described 16S rRNA sequences of halophilic archaea deposited in the EMBL database. The sequences were aligned by using CLUSTAL w 1.74 (Thompson et al., 1994), and phylogenetic trees were constructed by using programs in version 3.5.1 of PHYLIP (Felsenstein, 1993). We determined a matrix of evolutionary distances from the sequence alignment data, using the Jukes-Cantor model (Jukes \& Cantor, 1969). A phylogenetic tree was constructed from the distance matrix by using the program FITCH, which uses the leastsquares algorithm (Fitch \& Margoliash, 1967).

\section{RESULTS}

\section{Characterization and culture conditions}

The specific phenotypic characteristics and lipid compositions of the Halorubrum strains studied are shown in Table 2. In addition, all strains were pleomorphic, showing irregular shapes (discs, squares, ovals), and were Gram-negative. They grew optimally in the 


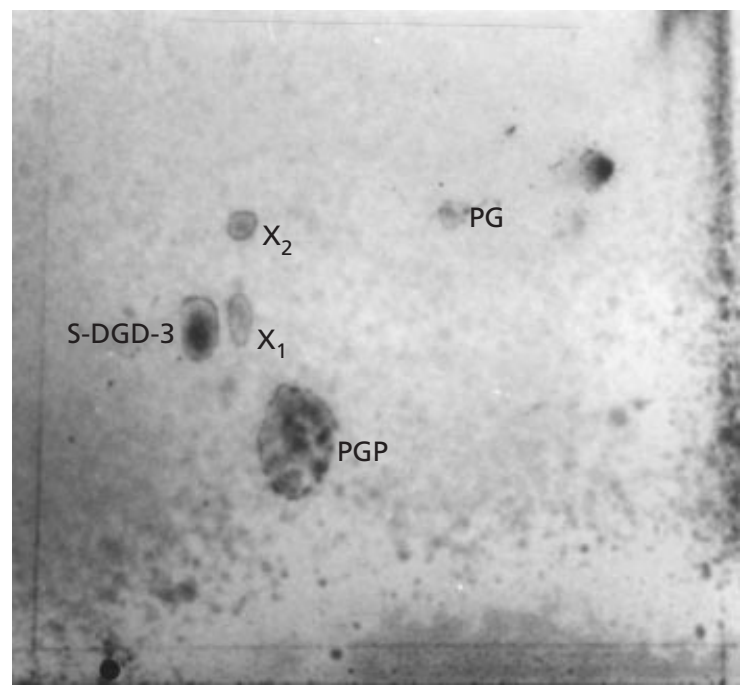

Fig. 1. Polar lipid composition of strain $A L T 6-92^{\top}$ separated by two-dimensional TLC (for conditions, see Methods). PG, phosphatidylglycerol; PGP, phosphatidylglycerophosphate; S-DGD-3, mannosyl-2-sulfate-(1-4)-glycosyl-archaeol; $X_{1}$ and $\mathrm{X}_{2}$, unknown glycolipids. Direction of development: first dimension, vertical; second dimension, horizontal. The origin is in the bottom left-hand corner.

presence of $5 \cdot 2 \mathrm{M} \mathrm{NaCl}(30 \%, \mathrm{w} / \mathrm{v}$, total salts) at $40{ }^{\circ} \mathrm{C}$ in the $\mathrm{HE}$ medium. They did not require magnesium for growth. The $\mathrm{pH}$ range was alkaline, and all of the strains grew between $\mathrm{pH} 7 \cdot 0$ and $\mathrm{pH} 10 \cdot 0$. The cultures were orange-red. Growth was susceptible to novobiocin $(30 \mu \mathrm{g})$ and bacitracin $(10 \mathrm{U})$ and resistant to penicillin $\mathrm{G}(10 \mathrm{U})$, kanamycin $(30 \mu \mathrm{g})$, tetracycline $(30 \mu \mathrm{g})$, chloramphenicol $(30 \mu \mathrm{g})$, erythromycin $(15 \mu \mathrm{g})$, gentamicin $(10 \mu \mathrm{g})$ and streptomycin $(10 \mu \mathrm{g})$.

The strains (ALT6-92 ${ }^{\mathrm{T}}$ and TeSe25-84) were isolated from water and sediment of Lake Tebenquiche, respectively, and proved to have very similar phenotypic properties and lipid compositions (Table 2). Strain ALT6-92 ${ }^{\mathrm{T}}$ was studied in further detail and was designated as the type strain of a new species of the genus Halorubrum. The cells were mostly irregularly disc-shaped and were catalase- and oxidase-positive. They did not hydrolyse gelatin, starch, Tween (20, 40, 60 or 80 ) or DNase. Indole was not formed. This strain produced $\mathrm{H}_{2} \mathrm{~S}$ from cysteine, reduced nitrate and hydrolysed aesculin. Acid was not produced. Growth on galactose, mannose, trehalose, glycerol, acetate and pyruvate as sole carbon and energy sources was observed.

\section{Lipid analyses}

We studied the lipid composition of strain ALT6-92 ${ }^{\mathrm{T}}$ together with some of the reference strains included in Table 1, to compare results. TLC of extracts of strain ALT6-92 ${ }^{\mathrm{T}}$ revealed that this organism contained phosphatidylglycerophosphate, phosphatidylglycerol and three glycolipids (Fig. 1). The major glycolipid was mannosyl-2-sulfate-(1-4)-glycosyl-archaeol (SDGD-3), a glycolipid characteristic of some species of genus Halorubrum. In addition, two unknown diglycosyldiethers, $\mathrm{X}_{1}$ and $\mathrm{X}_{2}$, were observed. Phosphatidylglycerosulfate was not detected in this strain (Table 2; Fig. 1), nevertheless, it was present in other strains in the genus Halorubrum.

\section{$\mathbf{G}+\mathbf{C}$ content determination}

The $\mathrm{G}+\mathrm{C}$ contents of the 12 strains in the study and the reference strains were determined. The $\mathrm{G}+\mathrm{C}$ contents of the DNAs were between 60.5 and $63.2 \mathrm{~mol} \%$. The $\mathrm{G}+\mathrm{C}$ content for strain ALT6-92 was $63 \cdot 2 \pm 0.5 \mathrm{~mol} \%$.

\section{Phylogenetic analysis}

A nearly complete $16 \mathrm{~S}$ rRNA gene sequence was obtained for strain ALT6-92 ${ }^{\mathrm{T}}$. The evolutionary distance between strain ALT6-92 $2^{\mathrm{T}}$ and others members of the genus Halorubrum was low (between 0.0346 and $0 \cdot 0881$ ), confirming its affiliation with other strains in the genus Halorubrum. Strain ALT6-92 ${ }^{\mathrm{T}}$ possessed the highest similarity with Halorubrum sodomense (96\%). The phylogenetic tree (Fig. 2) constructed for the Jukes-Cantor model and the least-squares algorithm of Fitch and Margoliash confirmed that strain ALT6$92^{\mathrm{T}}$ was closely related to the Halorubrum cluster.

\section{DNA-DNA hybridization}

The DNA-DNA hybridization experiments were performed with members of the genus Halorubrum. The pooled standard deviation of the different experiments was $1-4 \%$, indicating good correspondence between duplicates. The values obtained for strain ALT6-92 with strain TeSe25-84 showed that the isolates formed a homogeneous cluster with a high degree of internal genomic similarity (90-95\%) and should be considered as members of the same species. Closer investigation with respect to other members of the genus Halorubrum (Table 1) indicated that strain ALT6-92 was a member of this genus, but that it was sufficiently different from previously described Halorubrum species to warrant the description of a novel species.

\section{DISCUSSION}

Previous studies of the Atacama Saltern have found a heterogeneous prokaryotic population that is represented by halotolerant bacteria, moderately halophilic bacteria and extremely halophilic archaea and cyanobacteria (Campos et al., 1990). Strain ALT6-92 ${ }^{\mathrm{T}}$ was isolated from the water of Lake Tebenquiche.

The polar lipids and glycolipids have proved useful, particularly for the differentiation of the genera of haloarchaea, e.g. Haloarcula and Haloferax (Torreblanca et al., 1986), Halobaculum (Oren et al., 1995) and Natrialba (Kamekura \& Dyall-Smith, 1995). Although members of the genus Halorubrum have slight differences in their glycolipid content, with few 


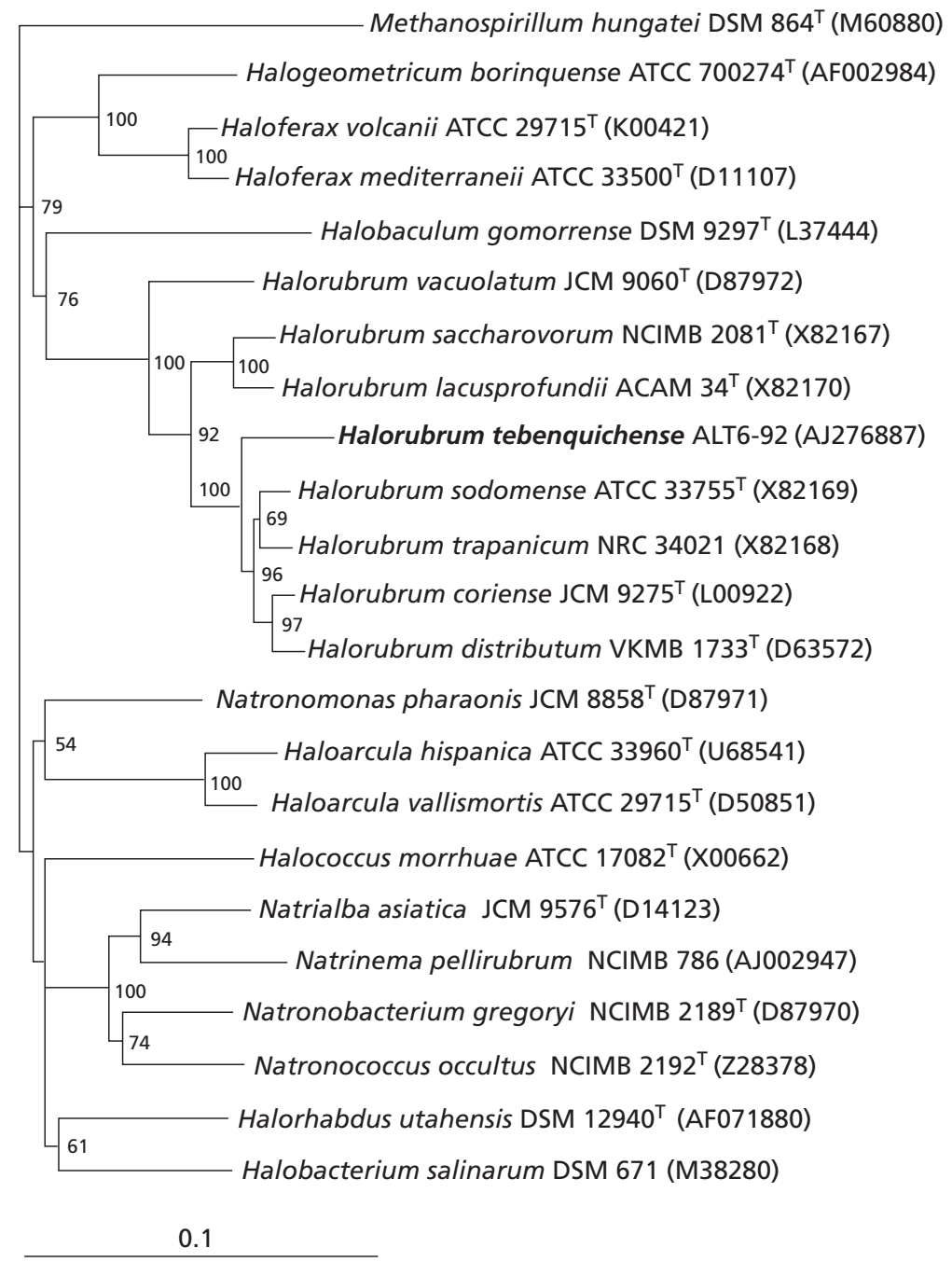

Fig. 2. Phylogenetic tree showing the position of Halorubrum tebenquichense ALT6-92 ${ }^{\top}$ among the species representatives of genus Halorubrum and some genera of extremely halophilic archaea. The sequence data used were obtained from the EMBL database (accession numbers are given in parentheses). The sequence of Methanospirillum hungatei DSM $864^{\top}$ was used as the outgroup. Bootstrap values (greater than 50) are shown at the nodes. Bar, 0.1 substitution per nucleotide position.

Table 3. Differential characteristics of the strain ALT6- $92^{\top}$ and the described species of the genus Halorubrum

Data were obtained from Torreblanca et al. (1986), Grant \& Larsen (1990), Mwatha \& Grant (1993), Kamekura \& Dyall-Smith (1995) and McGenity \& Grant (1995). +, Positive result; -, negative result; ND, not determined.

\begin{tabular}{|c|c|c|c|c|c|c|c|}
\hline Characteristic & ALT6-92 $^{\mathrm{T}}$ & H. sodomense & H. saccharovorum & H. trapanicum & H. vacuolatum & H. lacusprofundi & H. coriensis \\
\hline Cell morphology & Irregular discs & Rods & Rods & Pleomorphic rods & $\begin{array}{l}\text { Pleomorphic } \\
\text { short rods }\end{array}$ & Pleomorphic rods & $\begin{array}{l}\text { Pleomorphic short } \\
\text { rods and cup shapes }\end{array}$ \\
\hline Cell dimensions $(\mu \mathrm{m})$ & $1.2-0.8 \times 1.0-1.5$ & $0.5 \times 2.5-5$ & $0.6-1 \cdot 2 \times 2.5$ & $0.7-10 \times 1.5-3.0$ & $0 \cdot 7-10 \times 1.5-3.0$ & $>12$ & $5-0.5$ \\
\hline $\begin{array}{l}\text { Range for growth in } \\
\mathrm{NaCl}(\mathrm{M})\end{array}$ & $2 \cdot 5-5 \cdot 2$ & $0 \cdot 5-4 \cdot 3$ & $1 \cdot 5-5 \cdot 2$ & ND & $2 \cdot 5-5 \cdot 1$ & $>1$ & $2 \cdot 2-2 \cdot 7$ \\
\hline Starch hydrolysis & - & + & - & - & - & - & $\mathrm{ND}$ \\
\hline \multicolumn{8}{|l|}{ Acid from: } \\
\hline Glucose & - & + & + & + & ND & - & + \\
\hline Xylose & - & + & + & - & ND & ND & ND \\
\hline Glycolipids* & S-DGD-3 $X_{1}, X_{2}$ & S-DGD-3 & S-DGD-3 & S-DGD-5 & - & S-DGD-3 & S-DGD-3 \\
\hline $\mathrm{G}+\mathrm{C}$ content $(\mathrm{mol} \%) \dagger$ & $63 \cdot 2\left(T_{\mathrm{m}}\right)$ & $68(\mathrm{Bd})$ & $71 \cdot 2(\mathrm{Bd})$ & $64 \cdot 3(\mathrm{Bd})$ & $62 \cdot 7\left(T_{\mathrm{m}}\right)$ & $65 \cdot 3-65 \cdot 8(\mathrm{Bd}) 54 \cdot 8-56 \cdot 5$ & ND \\
\hline
\end{tabular}

* $\mathrm{X}_{1}, \mathrm{X}_{2}$, unknown glycolipids; S-DGD-3, mannosyl-2-sulfate-(1-4)-glycosyl-archaeol; S-DGD-5, mannosyl-2-sulfate-(1-2)-glycosylarchaeol.

$\dagger T_{\mathrm{m}}$, melting temperature; Bd, buoyant density.

exceptions they all contain a glycosyl-mannosyl coresulfated diglicosyl diether (McGenity \& Grant, 1995). Even though this glycolipid has not been detected in
Halorubrum vacuolatum, the presence of S-DGD-3 is characteristic of the other members of this genus (Mwatha \& Grant, 1993). Strain ALT6-92 ${ }^{\mathrm{T}}$ possessed 
a polar lipid pattern similar that to found in the genus Halorubrum (Trincone et al., 1990). Both phosphatidylglycerophosphate and phosphatidylglycerol were detected, the major glycolipid being S-DGD-3; two unknown glycolipids $\left(\mathrm{X}_{1}\right.$ and $\left.\mathrm{X}_{2}\right)$ were also present. Analysis of 16S rDNA gene sequences further confirms that strain ALT6-92 $2^{\mathrm{T}}$ is a member of the genus Halorubrum, there being $>95 \%$ sequence similarity and evolutionary distances of $0.0346-0.0881$ with other species of the genus.

DNA hybridization is acknowledged as the superior method for the elucidation of relationships between closely related taxa, such as strains and species (Stackebrandt \& Goebel, 1994). The DNA-DNA relatedness between ALT6-92 ${ }^{\mathrm{T}}$ and species of the genus Halorubrum was in the range $38-55 \%$. Thus, strain ALT6-92 ${ }^{\mathrm{T}}$ appears to represent a novel genospecies within the genus Halorubrum (Wayne et al., 1987). Morever, differential phenotypic characteristics distinguish ALT6-92 $2^{\mathrm{T}}$ from the known species of Halorubrum (Table 3). This organism is of particular importance, as it grew in total salt concentrations of $2 \cdot 5-5 \cdot 2 \mathrm{M}$ and at $\mathrm{pH}$ values in the range 7.0-10.0. Magnesium was not required for growth.

The phenotypic and chemotaxonomic characteristics, together with the molecular and phylogenetic results, correspond with the minimal standards for the description of members of the Halobacteriales (Oren et al., 1997) and justify the creation of a new species.

\section{Description of Halorubrum tebenquichense sp. nov.}

Halorubrum tebenquichense (te.ben.qui.chen'se. N.L. adj. tebenquichense of the Tebenquiche, the hypersaline lake of Atacama Saltern).

Cell are irregularly disc-shaped $(1 \cdot 2-0 \cdot 8 \times 1 \cdot 0-1 \cdot 5 \mu \mathrm{m})$. Gram-negative. The colonies are red-orange in agar plates containing $25 \%(\mathrm{w} / \mathrm{v})$ total salts, and orange in medium at $15-20 \%(\mathrm{w} / \mathrm{v})$ total salts. Chemoorganotrophic and aerobic. Grows in the presence of $2 \cdot 5-5 \cdot 2 \mathrm{M} \mathrm{NaCl}$ at $40{ }^{\circ} \mathrm{C}$. The temperature range is $35-50{ }^{\circ} \mathrm{C}$ and the $\mathrm{pH}$ range is $7 \cdot 0-10 \cdot 0$. Magnesium is not required for growth. Catalase- and oxidasepositive. $\mathrm{H}_{2} \mathrm{~S}$ is produced from cysteine, and nitrate is reduced. Aesculin is hydrolysed. No acid is produced from sugars and polyols. Glucose, fructose, galactose, mannose, trehalose, acetate and pyruvate are used as carbon and energy sources. Susceptible to novobiocin $(30 \mu \mathrm{g})$ and bacitracin $(10 \mathrm{U})$. The polar lipids are glycerol diether analogues of phosphatidylglycerol and phosphatidylglycerophosphate. Phosphatidylglycerosulfate is not detected. The major glycolipid is $\mathrm{S}$ DGD-3 and two minor glycolipids $\left(\mathrm{X}_{1}\right.$ and $\left.\mathrm{X}_{2}\right)$. Isolated from hypersaline Lake Tebenquiche situated in the Atacama Saltern, Chile. The $\mathrm{G}+\mathrm{C}$ content of the DNA is $63.2 \mathrm{~mol} \%\left(T_{\mathrm{m}}\right)$. The type strain is ALT6-92 ${ }^{\mathrm{T}}$ and has been deposited in the Colección Española de Cultivos Tipo, Valencia, Spain as CECT $5317^{\mathrm{T}}\left(=\mathrm{DSM} 14210^{\mathrm{T}}\right)$.

\section{ACKNOWLEDGEMENTS}

This study was supported, in part, by grants from the Volkswagen Stiftung (project 1/64.465), Germany, the Junta de Andalucia (project CVI 190), Spain, and DGI-UCV, Chile.

\section{REFERENCES}

Bligh, E. G. \& Dyer, W. J. (1959). A rapid method of total lipid extraction and purification. Can J Biochem Physiol 37, 911-917.

Campos, V., Prado, B., Lizama, C., Péndola, L. \& Robledano, M. (1990). Prokaryotes of saline environments in the Atacama Salar. In Proceedings of the 2nd Biennial Water Quality Symposium, pp. 275-279. Edited by G. Castillo, V. Campos \& L. Herrera. Santiago: Chile: University Editorial.

Dussault, H. P. (1955). An improved technique for staining halophilic bacteria. J Bacteriol 70, 484-485.

Felsenstein, J. (1993). PHYLIP (phylogeny inference package), version 3.5.1. Department of Genetics, University of Washington, Seattle.

Fitch, W. M. \& Margoliash, E. (1967). Construction of phylogenetic trees based on mutation distance as estimated from cytochrome c sequences is of general applicability. Science $\mathbf{1 5 5}$, 279-284.

González, C., Gutierrez, C. \& Ramirez, C. (1978). Halobacterium vallismortis sp. nov. An amylolytic and carbohydratemetabolizing, extremely halophilic bacterium. Can J Microbiol 24, 710-715.

Grant, W. D. \& Larsen, H. (1990). Extremely halophilic archaebacteria, order Halobacteriales ord. nov. In Bergey's Manual of Systematic Bacteriology, vol. 3, pp. 2216-2233. Edited by J. T. Staley, M. P. Bryant, N. Pfennig \& J. G. Holt. Baltimore: Williams \& Wilkins.

Juez, G., Rodríguez-Valera, F., Ventosa, A. \& Kushner, D. J. (1986). Haloarcula hispanica spec. nov. and Haloferax gibbonsii spec. nov., two new species of extremely halophilic archaebacteria. Syst Appl Microbiol 8, 75-79.

Jukes, T. H. \& Cantor, C. R. (1969). Evolution of protein molecules. In Mammalian Protein Metabolism, vol. 3, pp. 21-132. Edited by H. N. Munro. New York: Academic Press.

Kamekura, M. \& Dyall-Smith, M. (1995). Taxonomy of the family Halobacteriaceae and the description of two new genera Halorubrobacterium and Natrialba. J Gen Appl Microbiol 41, 333-350.

Kamekura, M., Dyall-Smith, M. L., Upasani, V., Ventosa, A. \& Kates, M. (1997). Diversity of alkaliphilic halobacteria: proposals for transfer of Natronobacterium vacuolatum, Natronobacterium madadii, and Natronobacterium pharaonis to Halorubrum, Natrialba, and Natronomonas gen. nov., respectively, as Halorubrum vacuolatum comb. nov., Natrialba magadii comb. nov., and Natronomonas pharaonis comb. nov., respectively. Int J Syst Bacteriol 47, 853-857.

Kates, M. (1972). Ether-linked lipids in extremely halophilic bacteria. In The Ether Bond in Lipids, pp. 351-398. Edited by F. Snyder. New York: Academic Press.

Lind, E. \& Ursing, J. (1986). Clinical strains of Enterobacter agglomerans (synonyms, Erwinia herbicola, Erwinia milletiae) identified by DNA-DNA hybridization. Acta Pathol Microbiol Immunol Scand Sect B Microbiol 94, 205-213.

McGenity, T. J. \& Grant, W. D. (1995). Transfer of Halobacterium saccharovorum, Halobacterium sodomense, Halobacterium trapanicum NRC 34021 and Halobacterium lacusprofundi to the 
Genus Halorubrum gen. nov., as Halorubrum saccharovorum comb. nov., and Halorubrum sodomense comb. nov., Halorubrum trapanicum comb. nov., and Halorubrum lacusprofundi comb. nov. Syst Appl Microbiol 18, 237-243.

Marmur, J. \& Doty, P. (1962). Determination of the base composition of deoxyribonucleic acid from its thermal denaturation temperature. J Mol Biol 5, 109-118.

Mwatha, W. E. \& Grant, W. D. (1993). Natronobacterium vacuolata sp. nov., a haloalkaliphilic archaeon isolated from Lake Magadi, Kenya. Int J Syst Bacteriol 43, 401-404.

Ollivier, B., Caumette, P., Garcia, J. L. \& Mah, R. A. (1994). Anaerobic bacteria from hypersaline environments. Microbiol Rev 58, 27-38.

Oren, A. (1983). Halobacterium sodomense sp. nov., a Dead Sea Halobacterium with an extremely high magnesium requirement. Int J Syst Bacteriol 33, 381-386.

Oren, A., Gurevich, P., Gemmell, R. T. \& Teske, A. (1995). Halobaculum gomorrense gen. nov., sp. nov., a novel extremely halophilic archaeon from the Dead Sea. Int J Syst Bacteriol 45, 747-754.

Oren, A., Duker, S. \& Ritter, S. (1996). The polar lipid composition of Walsky's square bacterium. FEMS Microbiol Lett 138, 135-140.

Oren, A., Ventosa, A. \& Grant, W. D. (1997). Proposed minimal standards for description of new taxa in the order Halobacteriales. Int J Syst Bacteriol 47, 233-238.

Prado, B., Del Moral, A., Quesada, E., Ríos, R., MonteolivaSanchez, M., Campos, V. \& Ramos-Cormenzana, A. (1991). Numerical taxonomy of moderately halophilic Gram negative rods isolated from the Salar of Atacama, Chile. Syst Appl Microbiol 14, 275-281.

Prado, B., Del Moral, A. \& Campos, V. (1993). Distribution and types of heterotrophic halophilic flora from Salar of Atacama,Chile. Toxicol Environ Chem 38, 163-166.

Rodríguez-Valera, F. \& Ruiz-Berraquero, F. (1983). Halobacterias. Investig Cienc 80, 94-102 (in Spanish).

Rodríguez-Valera, F., Ruiz-Berraquero, F. \& Ramos-Cormenzana, A. (1980). Isolation of extremely halophilic bacteria able to grow in defined inorganic media with single carbon sources. $J$ Gen Microbiol 119, 535-538.

Rodríguez-Valera, F., Albert, F. J. \& Gibson, J. (1982). Effect of light on growing and starved populations of extremely halophilic bacteria. FEMS Microbiol Lett 14, 155-158.
Sanger, F., Nicklen, S. \& Coulson, A. R. (1977). DNA sequencing with chain-terminating inhibitors. Proc Natl Acad Sci U S A 74, 5463-5467.

Stackebrandt, E. \& Goebel, B. M. (1994). Taxonomic note: a place for DNA-DNA reassociation and 16S rRNA sequence analysis in the present species definition in bacteriology. Int $J$ Syst Bacteriol 44, 846-849.

Subov, N. N. (1931). Oceanographical Tables. Moscow: USSR Oceanographic Institute Hydrometeorological Commission.

Thompson, J. D., Higgins, D. G. \& Gibson, T. J. (1994). CLUSTAL $\mathrm{W}$ : improving the sensitivity of progressive multiple sequence alignment through sequence weighting, position-specific gap penalties and weight matrix choice. Nucleic Acids Res 22, 4673-4680.

Tindall, B. J., Ross, H. N. M. \& Grant, W. D. (1984). Natronobacterium gen. nov., and Natronococcus gen. nov., two new genera of haloalkaliphilic archaebacteria. Syst Appl Microbiol 5, 41-57.

Tindall, B. J., Tomlinson, G. A. \& Hochstein, L. I. (1987). Polar lipid composition of a new Halobacterium. Syst Appl Microbiol 9, 6-8.

Tomlinson, G. A. \& Hochstein, L. L. (1976). Halobacterium sacharovorum sp. nov., a carbohydrate-metabolizing, extremely halophilic bacterium. Can J Microbiol 22, 587-591.

Tomlinson, G. A., Jahnke, L. L. \& Hochstein, L. I. (1986). Halobacterium denitrificans sp. nov., an extremely halophilic denitrifying bacterium. Int J Syst Bacteriol 36, 66-70.

Torreblanca, M., Rodríguez-Valera, F., Juez, G., Ventosa, A., Kamekura, M. \& Kates, M. (1986). Classification of nonalkaliphilic halobacteria based on numerical taxonomy and polar lipid composition, and description of Haloarcula gen. nov. and Haloferax gen. nov. Syst Appl Microbiol 8, 89-99.

Trincone, A., Nicolaus, B., Lama, L., De Rosa, M., Gambacorta, A. \& Grant, W. D. (1990). The glycolipid of Halobacterium sodomense. J Gen Microbiol 136, 2327-2331.

Wayne, L. G., Brenner, D. J., Colwell, R. R. \& 9 other authors (1987). International Committee on Systematic Bacteriology. Report of the ad hoc committee on reconciliation of approaches to bacterial systematics. Int J Syst Bacteriol 37, 463-464.

Ziemke, F., Höfle, M. G., Lalucat, J. \& Rosselló-Mora, R. (1998). Reclassification of Shewanella putrefaciens Owen's genomic group II as Shewanella baltica sp. nov. Int J Syst Bacteriol 48, 179-186. 